\title{
DOSE RESPONSE OF INSULIN SECRETION TO INTRARUMINAL AND INTRAVENOUS INFUSIONS OF PROPIONATE IN SHEEP
}

\author{
H. Sano and Y. Terashima
}

Faculty of Animal Science, Kitasato University, Towada-shi Aomori 034, Japan

\section{Introduction}

In ruminants, volatile fatty acids (VFA) fermented by microorganisms in the rumen are the most important energy source for the animal. Propionate is the second most abundant VFA following acetate in both the rumen and blood, and is also a major precursor of glucose in the ruminants. Insulin is one of the key hormones controlling peripheral glucose utilization and hepatic gluconeogenesis. At pharmacological levels propionate stimulates insulin secretion in ruminants unlike that in non-ruminants. However, the physiological significance of propionate-induced insulin secretion is not clear (Stern, et al., 1970; Brockmen, 1985).

This experiment was designed to study the effects of physiological doses of propionate administered either into the rumen or intravenously on insulin secretion in sheep.

\section{Materials and Methods}

The experimental animals were four yearling Suffolk rams, weighing about $45 \mathrm{~kg}$, which had been surgically fitted with a skin loop enclosing the left carotid artery and with a rumen cannula. Animals were kept in metabolic cages in a laboratory room at air temperatures of $21^{\circ} \mathrm{C}$ for more than a month. They were fed $15 \% \mathrm{CP}$ lucerne hay cubes at $2 \%$ of $\mathrm{BW}$ and $17 \% \mathrm{CP}$ commercial concentrate at $0.5 \%$ of $\mathrm{BW}$ one daily. A polyethylene catheter for the intravenous propionate infusion was inserted into a femoral vein 2 days before the initiation of experiments. Propionate solutions for the intraruminal and intravenous infusions were $3.8 \mathrm{M}(\mathrm{pH} \mathrm{5.5)}$ and $1.2 \mathrm{M}(\mathrm{pH} \mathrm{7.4)}$, respectively. Propionate was infused continuously by a multichannel peristatic pump for $30 \mathrm{~min}$ at constant rates of $16,32,64,128,256$ and 512 $\mu \mathrm{mol} / \mathrm{kg} \mathrm{BW} / \mathrm{min}$ through the rumen cannula, and of 0 (saline only), 1, 2, 4, 8, 16, 32 and 64 $\mu \mathrm{mol} / \mathrm{kg} \mathrm{BW} / \mathrm{min}$ through the femoral vein cathe- ter. Each sheep was subjected to all levels of propionate infusion in an completely randomized manner. An arterial catheter was placed in the skin loop at least $2 \mathrm{hrs}$ before the initation of blood sampling. Arterial samples were taken at $-10,0$ (baseline), $1,2.5,5,10,15,30,45,60$, 90 and $120 \mathrm{~min}$ after the start of the propionate infusion. Insulin was assayed by a radioimmunoassay. The insulin area, defined as the area beneath the curve for insulin concentration, was calculated over $120 \mathrm{~min}$ after the start of the propionate infusion. Data was analyzed by t-test.

\section{Results and Discussion}

While plasma insulin concentrations and insulin areas remained unchanged with intraruminal propionate infusions at the rates of 16,32 and 64 $\mu \mathrm{mol} / \mathrm{kg} \mathrm{BW} / \mathrm{min}$, they increased dose-dependently at rates of $128 \mu \mathrm{mol}$ propionate $/ \mathrm{kg} \mathrm{BW} / \mathrm{min}$ and above (table 1). The plasma insulin concentration increased progressively after the initiation of propionate infusion, reached a peak at 30 to $45 \mathrm{~min}$

TABLE 1. EFFECT OF INTRARUMINAL INFUSION OF PROPIONATE ON INSULIN LEVELS AND INSULIN AREA IN SHEEP

\begin{tabular}{|c|c|c|c|c|c|c|c|}
\hline \multirow{3}{*}{$\begin{array}{c}\text { Propionate } \\
\text { dose }\end{array}$} & \multicolumn{5}{|c|}{ Insulin $(\mu \mathrm{U} / \mathrm{ml})$} & \multirow{2}{*}{\multicolumn{2}{|c|}{$\begin{array}{c}\text { Insulin area } \\
(\mathrm{mU} / \mathrm{ml} \text { per } \\
120 \mathrm{~min})\end{array}$}} \\
\hline & \multicolumn{3}{|c|}{ Baseline } & & & & \\
\hline & Mean & SD & & & & Mean & $\mathrm{SD}$ \\
\hline 16 & 8 & 3 & & 10 & 2 & 1.0 & 0.3 \\
\hline 32 & 9 & 2 & & 10 & 7 & 1.1 & 0.3 \\
\hline 64 & 8 & 2 & & 9 & 3 & 1.0 & 0.3 \\
\hline 128 & 7 & 2 & + & 12 & 5 & 1.2 & $0.3^{* *}$ \\
\hline 256 & 8 & 2 & & 25 & 11 & 1.9 & $0.4 *$ \\
\hline 512 & 9 & 2 & + & 113 & $63^{*}$ & 4.7 & $1.8 * *$ \\
\hline
\end{tabular}

Significance of difference between baseline and peak insulin, $+p<0.05$

Significance of difference between $16 \mu \mathrm{mol} / \mathrm{kg} \mathrm{BW} /$ $\min$ and $32,64,128,256$ or $516 \mu \mathrm{mol} / \mathrm{kg} \mathrm{BW} / \mathrm{min}$, $* \mathrm{p}<0.05, * * \mathrm{p}<0.01$ 
and, thereafter, gradually declined to the initial levels.

When propionate was infused intravenously, plasma insulin concentrations remained unchanged at rates of less than $4 \mu \mathrm{mol} / \mathrm{kg} \mathrm{BW} / \mathrm{min}$, and increased dose-dependently with rates of $8 \mu \mathrm{mol} / \mathrm{kg}$ $\mathrm{BW} / \mathrm{min}$ and above. Insulin reached a peak at 2.5 to $10 \mathrm{~min}$ and then decreased to the initial levels for propionate infusion rates of $8 \mu \mathrm{mol} / \mathrm{kg} \mathrm{BW} /$ min and above (table 2). The plasma insulin response to the intravenous infusion was very rapid, compared with that of intraruminal infusions. In-

TABLE 2. EFFECT OF INTRAVENOUS INFUSION OF PROPIONATE ON INSULIN LEVELS AND INSULIN AREA IN SHEEP

\begin{tabular}{|c|c|c|c|c|c|c|c|}
\hline \multirow{3}{*}{$\begin{array}{l}\text { Propionate } \\
\text { dose }\end{array}$} & \multicolumn{5}{|c|}{ Insulin $(\mu \mathrm{U} / \mathrm{ml})$} & \multirow{2}{*}{\multicolumn{2}{|c|}{$\begin{array}{c}\text { Insulin area } \\
\text { ( } \mathrm{mU} / \mathrm{ml} \text { per } \\
120 \mathrm{~min})\end{array}$}} \\
\hline & \multicolumn{2}{|c|}{ Baseline } & \multicolumn{3}{|c|}{ Peak } & & \\
\hline & Mean & SD & & Mean & SD & Mean & SD \\
\hline Saline & 12 & 2 & & 13 & 2 & 1.4 & 0.3 \\
\hline 1 & 12 & 3 & & 14 & 3 & 1.5 & 0.3 \\
\hline 2 & 10 & 2 & & 14 & 7 & 1.3 & 0.3 \\
\hline 4 & 11 & 2 & + & 15 & 2 & 1.4 & 0.2 \\
\hline 8 & 11 & 2 & ++ & 30 & $5 * *$ & 1.7 & 0.3 \\
\hline 16 & 13 & 2 & + & 86 & $36 *$ & 2.7 & $0.6 * *$ \\
\hline 32 & 11 & 3 & ++ & 140 & $34 * *$ & 4.0 & $1.1 *$ \\
\hline 64 & 13 & 3 & ++ & 250 & $84 * *$ & 6.6 & $2.0 * *$ \\
\hline
\end{tabular}

Significance of difference between baseline and peak insulin, $+\mathrm{p}<0.05,++\mathrm{p}<0.01$

Significance of difference between saline and propionate infusions, $* \mathrm{p}<0.05, * * \mathrm{p}<0.01$

creases in insulin areas were observed for rates of $16 \mu \mathrm{mol}$ propionate $/ \mathrm{kg} \mathrm{BW} / \mathrm{min}$ and above, and compared with that of saline infusions.

In order to estimate the minimum propionate dose for insulin secretion when administered into either the rumen or the blood, the relationships between the insulin area and propionate infusion rate were plotted on a logarithmic scale. Regression equations were determined for the insulin insensitive and sensitive propionate infusion rates separately. The point of intersection of these two regression lines, which could be taken to represent the minimum propionate dose for insulin secre- tion, was 114.5 and $6.1 \mu \mathrm{mol} / \mathrm{kg} \mathrm{BW} / \mathrm{min}$ for the intraruminal and intravenous infusions, respectively. The daily production rate in the rumen and net portal absorption rate of propionate were estimated to be 0.9 and $0.44 \mathrm{~mol} / \mathrm{day}$ in sheep fed $800 \mathrm{~g}$ hay per day (Bergman, 1975). Though this data could not be compared directly with the present results because of the short period of propionate infusion in the present experiment, the minimum intraruminal propionate dose for insulin secretion appears to be greater than the mean propionate production rate in the rumen. When propionate was infused intravenously, the minimum propionate dose for insulin secretion was comparable to the net portal propionate absorption rate (Bergman, 1975). Circulating propionate may thus appear to be more physiologically relevant as a stimulus for insulin secretion in sheep. However, arterial propionate levels at the minimum propionate dose for insulin secretion may be out of the physiological range, because propionate absorbed in the alimentary tract is almost completely removed by the liver. Further studies will be necessary, including portal infusions of propionate, before we can reach a conclusion regarding the physiological significance of propionate for insulin secretion in ruminants.

(Key Words: Insulin, Propionate, Sheep)

\section{Literature Cited}

Bergman, E.N. 1975. Production and utilization of metabolites by the alimentary tract as measured in portal and hepatic blood. In "Digestion and Metabolism in the Ruminant" (Ed by I.W. McDonald and A.C.I. Warner) The University of New England Publishing Unit, pp. 292-305.

Brockman, R.P. 1985. Pancreatic and adrenal hormonal regulation of metabolism. In "Control of Digestion and Metabolism in Ruminants" (Ed by L.P. Milligan, W.L. Grovum and A. Dobson) A Reston Book, pp.405-419.

Stern, J.S., C.A. Baile and J. Mayer. 1970. Are propionate and butyrate physiological regulators of plasma insulin in ruminants? Am. J. Physiol. 219:84-91. 